\title{
AN ANALYSIS OF THE INFLUENCE OF TRANSFORMATIONAL LEADERSHIP AND ORGANIZATIONAL COMMITMENTS ON CHANGE READINESS
}

\begin{abstract}
Organizations that cannot adapt to changes will be eliminated by competitors and unable to maintain their existence. Organizational changes require organizational readiness, for example, from a human resources perspective. An important factor affecting the readiness for change is transformational leadership, in which the role of the leader is to direct, guide and motivate the team to implement changes, and build the trust on facing or implementing organizational changes. Moreover, due to the high organizational commitment of employees, it can help to implement further company strategies to respond to the changes. This study aims to review various previous research that discuss transformational leadership, organizational commitment, and change preparation. Literature studies is previous findings related to transformational leadership, organizational commitment, and change readiness that used as research methodology and a coherent analysis. The results indicated that: 1) there is a positive influence between transformational leadership and change readiness; 2) there is positive influences between organizational commitment and change readiness.
\end{abstract}

Keywords: Transformational Leadership, Organization Commitment, Change readiness.

\section{INTRODUCTION}

Under the rapid global development, there are new business risks found, the exciting opportunity, innovation and new leadership system which can cause the changes that continuously experienced by organization (Madsen et al., 2005). In facts, an organization continues to face other challenges and new problem appears, therefore it is needed to implement a development or a change in order to survive during the competition. There is none of organization located on stable environment, even in a bigger company, which has a big impact of market domination, should experience a change. Continuous implementation of changes can quickly improve the performance of senior organizations, therefore it is able to reach success in an organization and vice versa. The organization or the company that cannot adapt to the changes will be defeated by a competitor in order to maintain their existences. Organizational change requires organizational change readiness

1 Toufan Akbar, SE, Universitas Sebelas Maret Surakarta, Indonesia; e-mail: akbar0708@gmail. com (corresponding author). ORCID: 0000-0001-6563-829X,

2 Susanto Tirtoprojo, PhD, Universitas Sebelas Maret Surakarta, Indonesia; e-mail: susantotp57@gmail.com. ORCID: 0000-0002-2917-6072, 
in terms of Human Resources. Organizational change demands human resources to change, therefore employee change readiness is one of the important things to achieve the success of organizational or company development. Eby et al. (2000) explains that the change is needed as a support of a company or an organization, and employee's support is also needed to prepare change readiness. According to Desplaces (2005), positive factors that lead to the changes is the readiness of individual changes, individual readiness will have an impact on focus, feeling and mind set of the attitude and behaviour, if an individual is ready they will be able to adjust himself to the changes. It can decrease the influence on the successful of change. Holt et al. (2007) argues that change readiness is a multidimensional form that influenced by beliefs of employees which are able to implement the change specific efficacy, the proposed change is related to the appropriateness, the leader commitment to the changes which proposes a benefit for organization (personal valence). The readiness of an individual to change is an important factor of organizational success to implement the changes (Bernerth, 2004).

Under the conditions of organizational change, employee demand to leave their previous comfort zone, however, not every employee is ready to change. Furthermore, the organizational commitment has an important role to provide change readiness of workers. According to Meyer \& Allen (1991), organizational commitments have 3 dimensions that consist of affective, sustainable and normative commitment. The affective commitment is an employee's emotional attachment, identification, and participation in organization. The sustainable commitment is a commitment based on the company disadvantage regarding the employee resignation. While, the meaning of normative commitment is the individual feelings obliged to stay loyal to their organization. In the research by Durkin and Bennett (1999) it was revealed that high organizational commitment of employees can help the implementation of company strategy to deal with change. The organizational commitment is a strong will of individual to become an organization member, the willingness to work related to the organizational expectations, certain belief by accepting value and purpose of organization (Luthans, 2012).

The other important factor that influences the change readiness is transformational leader, whose role is to direct, guide and motivate the team to implement the change and built the trust on facing the organizational change. According to Hughes et al. (2012), transformational leadership has a vision, rhetoric and management skills to develop the strong emotional relationship between leaders and their team. The initial idea related to transformational leadership goes along with the concept of transactional leadership which implies in political context. Transformational leadership is believed to be more successful in obtaining organizational change because of the development of followers' emotions and the workers willingness to manifesting the leader's vision, while transactional leadership does not reflect the characteristics of leader, which is able to develop strong emotional relationship with the team and inspires the team to done their job beyond what they should be done.

Walumbwa et al. (2008) stated that transformational leadership is one of leadership styles that support the change readiness because transformational leadership can help to improve the effectiveness of employees and provide encouragement "can definitely do!" Transformational leadership is the leadership style that inspires and motivate the employees to implements the job beyond the expectation and their own interests for the benefit of organization, the empirical proof was found in the research that implemented by Kartika (2016) which proofed that transformational leadership influenced the readiness for change. 
Based on the explanation above, this research aims to review the problem of transformational leadership and organizational commitment concerning the change readiness in an organization. Several research that examines the influence of transformational leadership and organizational commitment on the change readiness has been done many times in different way. Researchers' interests to review the study about the change readiness of worker which influenced by transformational leadership and organizational commitment, then resume it in order to give the recommendation in order to improve the change readiness until the resistance of the changes can decrease and the influenced on the possibility of changes is getting bigger.

\section{LITERATURE REVIEW}

\subsection{Transformational Leadership}

Transformative leader is a leader who creates trust, loyalty, admiration, and respect for his followers and among adherents and leaders. The transformational leadership's supporters believe that they are voluntarily ready to achieve the goals, objectives and vision of the organization. Robbins (2001) stated that transformative leader is a person who inspires the followers to changes their life and affirms that transformational leadership is able to aspire to bigger targets and visions. Transformative leader is willing to do anything best to achieve the organizational targets, to motivate, and to raise his followers morale (Sari, 2018).

\subsection{Organizational Commitment}

A worker can show different levels of commitment based on what he believes. By studying the level of commitment can predict how a worker is involved in organizational commitment and the factors and the relationship between the factors. Commitment is part of the responsibility for the job given. Workers believe that they are required to devote themselves to achieving organizational goals, their existence in the organization. Therefore, they intend to stay in order to fulfill the obligations or contracts that they have signed. Where researchers believe that certain factors have a big impact on each component of commitment and different components of commitment show different levels of service (Novitasari et al., 2020).

\subsection{Readiness to Change}

Readiness to change is a necessity that must be experienced by an organization in order to be able to continue to adapt to a dynamic environment. Organizational change is defined as the act of shifting an organization from current conditions to the desired future conditions due to increase creativity. While, operational change is defined as a planned and unplanned transformation in the organizational structure, technology and/or the people within (Santhidran et al., 2013).

\subsection{The Influence of Transformational Leadership on Readiness to Change}

Change is often associated with leadership. Transformational and individual leadership are the perceptions of the readiness to change context, including; communication, organizational support, and alignment of organizational values (Sari, 2018). Transformational leadership is a changing process that will encourage employees to take 
initiatives change and reduce employees' reluctance to be more communicative and participative.

\subsection{The Influence of Organizational Commitment to Change Readiness}

Nordin (2011, as cited in Sari, 2018) added that affective commitment has a positive effect on change readiness through employee involvement through the change process and building the value that employees feel about the benefits of change can encourage employees to be ready to change. However, there are some studies that have found that affective commitment has a negative effect. Battisteli et al. (2014, cited in Sari, 2018) stated that one of the characteristics of affective commitment is high employee loyalty. When employees do not have a sense of loyalty, the intention to leave the organization is high, even though they are involved in the change process. An employee concerns about the costs that will arise if they do not provide support for company changes, and perceptions of the benefits that obtained if they participate in changes (Sari, 2018).

\section{RESEARCH METHODOLOGY}

This research used a qualitative approach. The method used is literature study which implemented by recording previous findings related to the variable of transformational leadership, organizational commitment, and change readiness. Then, combine the findings, analyzing the finding coherently and clearly.

This article used secondary data which was obtained from the several previous literatures. The supporting literature in this research comes from books and previous journal. The data analysis method used in this research is descriptive-qualitative analysis technique, the technique was chosen to illustrate the problems related to the change readiness then reviewed it back in order to produce relevant input and improve the change readiness until the resistance of changes can decreases and causes a great impact on the variable.

\section{RESULT AND DISCUSSION}

This research combined the result of several previous studies within the variable of $X_{1}$ transformational leadership and $\mathrm{X}_{2}$ organizational commitments to analyze the influences on Variable $\mathrm{Y}$ in the context of change readiness. There are the results and discussion related with the research problem.

\section{H1. The Influence of Transformational Leadership on the Change readiness}

The initial hypothesis proposed in this research is transformational leadership which has positive influence on the change readiness in the organization. There is several research that support the influence of transformational leadership toward change readiness.

Santhidran et al. (2013) stated that this research concerning the organizational change is not fully understood in the developing countries especially related with the changes of the process and inside this research found the proof that leadership gives the significant influence to the change readiness. The successful implementation of organizational change has become the important management task. The researcher in Taiwan gives addition of mechanism knowledge where the transformation leadership has influenced the behaviour supports to change the organization change (Chou et al., 2015). The finding of this study 
confirms the importance of transformational leadership in successful implementation of change.

The result of previous research by Bommer et al. (2005) found leader with transformational leadership style which effectively applie the change in the organization. The leaders have the characteristics of charismatic, visionary thinkers, and brave in taking the risk, out of the box and energize with having the ability to motivate the other people when acts as the role model and mentor for their followers. The other results also concluded that leader with the transformational characteristic is the positive change agency, able to cope the complex work environment and changing rapidly have the positive behavior to apply the evidence-based practice, and the end will positive influenced to the organization culture (Aarons, 2006; Mahalinga Shiva \& Suar, 2012; Murphy, 2005; Ward, 2002).

The comparison of the influence can be seen as the following table below:

Table 1. The Influence of Variable $\mathrm{X}_{1}$ toward Variable $\mathrm{Y}$

\begin{tabular}{|c|c|c|}
\hline Research Title & $\begin{array}{c}\text { Variable } \mathrm{X}_{1} \text { influence } \\
\text { Variable Y }\end{array}$ & $\begin{array}{c}\text { Variable } \mathrm{X}_{1} \text { has no influence } \\
\text { on Variable } \mathrm{Y}\end{array}$ \\
\hline $\begin{array}{l}\text { Enabling Organizational } \\
\text { Change Leadership, } \\
\text { Commitment to Change } \\
\text { and The Mediating Role of } \\
\text { Change Readiness } \\
\text { (Santhidran et al., 2013) }\end{array}$ & $\begin{array}{l}\text { Leadership positively and } \\
\text { significantly affects change } \\
\text { readiness but not commitment to } \\
\text { change }\end{array}$ & \\
\hline $\begin{array}{l}\text { Transformational } \\
\text { leadership and change } \\
\text { readiness and a } \\
\text { moderating role of } \\
\text { perceived bureaucratic } \\
\text { structure: an empirical } \\
\text { investigation (Abbasi, } \\
\text { 2017) }\end{array}$ & $\begin{array}{l}\text { Transformational Leadership } \\
\text { had a positive direct effect on } \\
\text { employee change readiness and } \\
\text { its dimensions }\end{array}$ & \\
\hline $\begin{array}{l}\text { Transformational } \\
\text { Leadership, Change } \\
\text { Management, and } \\
\text { Commitment to Change: } \\
\text { A Comparison of } \\
\text { Academic and Business } \\
\text { Organizations } \\
\text { (Cementina-Olpoc } \\
\text { \& Hechanova, 2013) }\end{array}$ & & $\begin{array}{l}\text { There were significant } \\
\text { differences in transformational } \\
\text { leadership between academic } \\
\text { and business organizations }\end{array}$ \\
\hline $\begin{array}{l}\text { Changing Attitudes about } \\
\text { Change: Longitudinal } \\
\text { Effects of } \\
\text { Transformational Leader } \\
\text { Behavior on Employee } \\
\text { Cynicism about } \\
\text { Organizational Change } \\
\text { (Bommer et al., 2005) }\end{array}$ & $\begin{array}{l}\text { Transformational leader } \\
\text { behaviors (TLB) generally were } \\
\text { associated with lower employee } \\
\text { Changing Attitude }\end{array}$ & \\
\hline
\end{tabular}


Based on the summary table above, three of four research result stated that there is a positive and significant influence of Transformational Leadership toward change readiness within the explanation as stated on the table above. And one of them stated that Transformational leadership did not have any effect on change readiness. Therefore, based on the majority of result, it can be indicated that Transformational Leadership has significant effect on Change readiness. It can be said that Hypothesis 1 is accepted.

\section{H2. The Effect of Organizational Commitment on the Change readiness}

The second hypothesis of this study is about the organizational commitment that has a positive influence on the change readiness in an organization. The success of organizational management determined by how organization manages Human Resource. The commitment of employees to the company determines the way of an organization to achieve the purpose. Human resource management presumes the employee commitment on valuable organization. Because, if the employee is committed to the company, the work result might be productive and ready to change on every condition, there are several organization entering the elements of commitment as the condition to hold a position offered in the job vacancy promotion because the role is important.

Table 2. The Influence of Variable $\mathrm{X}_{2}$ toward Variable $\mathrm{Y}$

\begin{tabular}{|c|c|c|}
\hline Research Title & $\begin{array}{c}\text { Variable } \mathrm{X}_{2} \text { influence } \\
\text { Variable Y }\end{array}$ & $\begin{array}{c}\text { Variable } X_{2} \text { has } \\
\text { no influence on } \\
\text { Variable } Y\end{array}$ \\
\hline $\begin{array}{l}\text { Readiness for organizational change: Do } \\
\text { organizational commitment and social } \\
\text { relationships in the workplace make a } \\
\text { difference? (Madsen et al., 2005) }\end{array}$ & $\begin{array}{l}\text { The findings indicate } \\
\text { significant relationships } \\
\text { between readiness for change } \\
\text { and organizational } \\
\text { commitment }\end{array}$ & \\
\hline $\begin{array}{l}\text { Organizational Culture Change and its } \\
\text { Effect on Change Readiness through } \\
\text { Organizational Commitment (Suwaryo } \\
\text { et al., 2015) }\end{array}$ & & $\begin{array}{l}\text { SEM analysis find out } \\
\text { that organizational } \\
\text { commitment } \\
\text { negatively affects the } \\
\text { readiness to change. }\end{array}$ \\
\hline $\begin{array}{l}\text { The influence of leadership behavior and } \\
\text { organizational commitment on } \\
\text { organizational readiness for change in a } \\
\text { higher learning institution (Nordin, } \\
\text { 2012) }\end{array}$ & $\begin{array}{l}\text { Transformational and } \\
\text { transactional leadership } \\
\text { behavior could contribute to } \\
\text { formulation of organizational } \\
\text { readiness for change and } \\
\text { subsequently lead to the } \\
\text { success of a change program. }\end{array}$ & \\
\hline $\begin{array}{l}\text { Employee Readiness for Organizational } \\
\text { Change: A Case Study in an Export } \\
\text { Oriented Manufacturing Firm in Sri } \\
\text { Lanka (Samaranayake, 2017) }\end{array}$ & $\begin{array}{l}\text { This article unveiled that } \\
\text { organizational commitment } \\
\text { and trust in peers and } \\
\text { management were } \\
\text { significantly and positively } \\
\text { correlated to employee } \\
\text { readiness for organizational } \\
\text { change. }\end{array}$ & \\
\hline
\end{tabular}


Based on the table of comparison above, three of four research stated that Organizational change positive and significantly influence change readiness. Only one research stated that organizational commitment negatively affect change readiness within the explanation as what it stated on the table above. Therefore, it can be said that Hypothesis 2 is accepted.

Furthermore, Allen and Meyer (1990) stated that organizational commitment reflected of three general components which affective commitment, continuance commitment, and normative commitment. According to Iverson (1996) the organizational commitment is the best predictor in the change than with the job satisfaction, the employee who has the high organizational commitment will put more effort into change projects to build positive attitudes toward change. Madsen et al. (2005) serves the finding in this research about the job satisfaction factor and change readiness, where the results show the organizational commitment has positive relationship for readiness that felt to change the organization. Al-Hussami et al. (2018) also deliver the research result to the nurse in the hospital there are three component of organizational commitment which accounts for a low to moderate amount of the readiness for change variant, this is shows that the organizational commitment has influenced on the change readiness.

\section{CONCLUSION}

Based on the result and the literature review that has been implemented through this research, it can be concluded that:

1) Transformational leadership has a positive influence on preparation for change. The positive relationship between each variable shows that transformational leaders can help to direct, guide, and motivate the team to implement changes and build trust in implementing organizational changes.

2) Organizational commitments have the positive impact on change readiness. Positive correlation between the variables indicates that if the employee's organizational commitment at a higher level, then the employee's readiness for change will be at a higher level too. Employees with a higher degree of organizational commitment will consistently show enthusiasm and positive attitude towards personal development, others or company

\section{SUGGESTION}

1) The leader needs to improve the communication with an employee, especially in delivering vision, mission, aim and purpose of the organization. Thus, the employee can be involved and be ready in the changing process. Besides, the leader is also needed to create comfortable and conducive work atmosphere in order to motivate the employees and improve employees' creativity.

2) In implementing the change, an organization needs to consider the employees' commitment as one of the important factors. Employees are the element of the company that must experience change to make the organization running well and success. Moreover, employees who are more prepared will see change not as a burden but as a challenge. 


\section{REFERENCES}

Aarons, G. A. (2006). Transformational and Transactional Leadership: Association With Attitudes Toward Evidence-Based Practice. "Psychiatric Services", 57(8). DOI: 10.1176/ps.2006.57.8.1162.

Abbasi, B. (2017). Transformational leadership and change readiness and a moderating role of perceived bureaucratic structure: an empirical investigation. "Problems and Perspectives in Management", 15(1). DOI: 10.21511/ppm.15(1).2017.03.

Al-Hussami, M., Hammad, S., Alsoleihat, F. (2018). The influence of leadership behavior, organizational commitment, organizational support, subjective career success on organizational readiness for change in healthcare organizations. "Leadership in Health Services", 31(4). DOI: 10.1108/LHS-06-2017-0031.

Allen, N. J., Meyer, J. P. (1990). The measurement and antecedents of affective, continuance and normative commitment to the organization. "Journal of Occupational Psychology", 63(1). DOI: 10.1111/j.2044-8325.1990.tb00506.x.

Bernerth, J. (2004). Expanding Our Understanding of the Change Message. "Human Resource Development Review", 3(1). DOI: 10.1177/1534484303261230.

Bommer, W. H., Rich, G. A., Rubin, R. S. (2005). Changing attitudes about change: longitudinal effects of transformational leader behavior on employee cynicism about organizational change. "Journal of Organizational Behavior", 26(7). DOI: 10.1002/ job.342.

Cementina-Olpoc, R., Hechanova, R. M. (2013). Transformational Leadership, Change Management, and Commitment to Change: A Comparison of Academic and Business Organizations. "Public Health", 22.

Chou, S., Chen, C.-W., Lin, J.-Y. (2015). Female online shoppers: Examining the mediating roles of e-satisfaction and e-trust on e-loyalty development. "Internet Research", 25(4).

Desplaces, D. (2005). A multilevel approach to individual readiness to change. "Journal of Behavioral and Applied Management", 7(1), 25.

Durkin, M., Bennett, H. (1999). Employee commitment in retail banking: identifying and exploring hidden dangers. "International Journal of Bank Marketing", 17(3). DOI: 10.1108/02652329910269239.

Eby, L. T., Adams, D. M., Russell, J. E. A., Gaby, S. H. (2000). Perceptions of Organizational Readiness for Change: Factors Related to Employees' Reactions to the Implementation of Team-Based Selling. "Human Relations", 53(3). DOI: 10.1177/0018726700533006.

Holt, D. T., Armenakis, A. A., Feild, H. S., Harris, S. G. (2007). Readiness for Organizational Change. "The Journal of Applied Behavioral Science", 43(2). DOI: $10.1177 / 0021886306295295$.

Hughes, R. L., Ginnet, R. C., Curphy, G. J. (2012). Leadership: Memperkaya Pelajaran dari Pengalaman (Edisi Ketu). Salemba Humanika.

Iverson, R. D. (1996). Employee acceptance of organizational change:the role of organizational commitment. "The International Journal of Human Resource Management", 7(1). DOI: 10.1080/09585199600000121.

Kartika, L. D. (2016). Pengaruh Transformational Leadership terhadap Readiness for Change melalui Employee Engagement sebagai variable intervening pada karyawan PT. SUPARMA, Tbk. Airlangga University.

Luthans, F. (2012). Perilaku Organisasi. Penerbit Andi. 
Madsen, S. R., Miller, D., John, C. R. (2005). Readiness for organizational change: Do organizational commitment and social relationships in the workplace make a difference? "Human Resource Development Quarterly", 16(2). DOI: 10.1002/hrdq.1134.

Mahalinga Shiva, M. S. A., \& Suar, D. (2012). Transformational Leadership, Organizational Culture, Organizational Effectiveness, and Programme Outcomes in Non-Governmental Organizations. "VOLUNTAS: International Journal of Voluntary and Nonprofit Organizations", 23(3). DOI: 10.1007/s11266-011-9230-4.

Meyer, J. P., Allen, N. J. (1991). A three-component conceptualization of organizational commitment. "Human Resource Management Review", 1(1). DOI: 10.1016/10534822(91)90011-Z.

Murphy, L. (2005). Transformational leadership: a cascading chain reaction. "Journal of Nursing Management", 13(2). DOI: 10.1111/j.1365-2934.2005.00458.x.

Nordin, N. (2012). The influence of leadership behavior and organizational commitment on organizational readiness for change in a higher learning institution. "Asia Pacific Education Review", 13.

Novitasari, D., Goestjahjanti, F. S., Asbari, M. (2020). The Role of Readiness to Change between Transformational Leadership and Performance: Evidence from a Hospital during Covid19 Pandemic. "APMBA (Asia Pacific Management and Business Application). DOI: 10.21776/ub.apmba.2020.009.01.4.

Samaranayake, anjee U. (2017). Employee Readiness for Organizational Change: A Case Study in an Export Oriented Manufacturing Firm in Sri Lanka. "Eurasian Journal of Business and Economics, 10(20),.DOI: 10.17015/ejbe.2017.020.01.

Santhidran, S., Chandran, V. G. R., \& Borromeo, J. (2013). Enabling Organizational Change Leadership, Commitment to Change and the Mediating Role of Change Readiness. "Journal of Business Economics and Management, 14(2). DOI: 10.3846/16111699.2011.642083

Sari, P. O. (2018). Pengaruh Gaya Kepemimpinan Transformational, Komitmen Afektif, Komitmen Kontinuans dan Komitmen Normatif terhadap Kesiapan berubah (Studi pada Bank BRI Kantor Wilayah Yogyakarta). "EXERO: Journal of Research in Business and Economics", 1(1). DOI: 10.24071/exero.2018.010104

Suwaryo, J., Daryanto, H. K. K., Maulana, A. (2015). Organizational Culture Change and its Effect on Change Readiness through Organizational Commitment. "BISNIS \& BIROKRASI: Journal Ilmu Administrasi Dan Organisasi", 22(1).

Walumbwa, F. O., Avolio, B. J., Zhu, W. (2008). How Transformational Leadeship Weaves its Influence on Individual Job Performance: The Role of Identification and Efficacy Beliefs. "Personnel Psychology", 61(4). DOI: 10.1111/j.1744-6570.2008.00131.x

Ward, K. (2002). A vision for tomorrow: Transformational nursing leaders. "Nursing Outlook", 50(3). https://doi.org/10.1067/mno.2002.123354

DOI: 10.7862/rz.2021.mmr.07

The text was submitted to the editorial office: March 2021.

The text was accepted for publication: June 2021. 
